\title{
Use of additives to improve the capacity of bituminous mixtures to be heated by means of microwaves
}

\author{
J. Gallego ${ }^{a} \bowtie$, M. A. del Val ${ }^{\mathrm{a}}$, V. Contreras ${ }^{\mathrm{b}}$, A. Páez ${ }^{\mathrm{b}}$ \\ a. Technical University of Madrid - UPM (Madrid, Spain) \\ b. Repsol Technology Centre - (Madrid, Spain) \\ \juan.gallego@upm.es
}

\author{
Received 13 January 2016 \\ Accepted 28 July 2016 \\ Available on line 14 February 2017
}

\begin{abstract}
This study examines the potential of adding electric arc furnace slag to bituminous mixtures to be heated by microwaves. The susceptibility of bituminous mixtures to microwave energy is limited and so, in order to improve the energy performance of the heating process, it is necessary to incorporate additives or components to the mixture so as to improve the capacity for microwave heating. The article presents the results of adding various components, (steel wool, scrap tire wire, silicon carbide, iron filings) and an alternative aggregate: electric arc furnace slag. According to the results obtained in the laboratory, slag addition of at least 5\% by weight of the bituminous mixture represents the best option for both technical and economic reasons. The results may promote the valorization of this steel industry residue in bituminous mixtures by improving microwave heating response.
\end{abstract}

KEYWORDS: Slag; Steel wool; Silicon carbide; Bituminous mixture; Microwave heating

Citation/Citar como: Gallego, J.; del Val, M.A.; Contreras, V.; Páez, A. (2017) Use of additives to improve the capacity of bituminous mixtures to be heated by means of microwaves. Mater. Construcc. 67 [325], e110. http://dx.doi. org/10.3989/mc.2017.00416

RESUMEN: Utilización de aditivos para mejorar la sensibilidad de las mezclas bituminosas al calentamiento con microondas. El presente trabajo examina el potencial de añadir escorias siderúrgicas de horno de arco eléctrico en mezclas bituminosas cuando se calientan con energía de microondas. La susceptibilidad de las mezclas bituminosas a las microondas es limitada y con el objetivo de incrementarla es necesario incorporar aditivos o componentes que sí son susceptibles. El artículo presenta los resultados obtenidos con varios aditivos (lana de acero, alambre metálico reciclado de neumáticos fuera de uso, carburo de silíceo y limaduras de hierro) y un árido alternativo: escorias de horno de arco eléctrico. De acuerdo con los resultados obtenidos en el estudio, la incorporación de escorias en al menos un 5\% en masa de la mezcla bituminosa representa la mejor opción por motivos técnicos y económicos. Este resultado puede potenciar la valorización de este residuo de la industria del acero en mezclas bituminosas para mejorar su respuesta al calentamiento con energía microondas.

PALABRAS CLAVE: Escorias; Lana de acero; Carburo de silício; Mezcla bituminosa; Calentamiento en microondas

ORCID ID: J. Gallego (http://orcid.org/0000-0002-1343-3185); M. A. del Val (http://orcid.org/0000-0002-5947-3289); V. Contreras (http://orcid.org/0000-0002-5499-7331); A. Páez (http://orcid.org/0000-0001-5210-5961)

Copyright: (C) 2017 CSIC. This is an open-access article distributed under the terms of the Creative Commons Attribution License (CC BY) Spain 3.0.

\section{INTRODUCTION}

Electric arc furnace slag (EAFS) has suitable properties for use in construction materials, provided that the $\mathrm{CaO}$ and $\mathrm{MgO}$ content is controlled.
These compounds can expand and cause disintegration of the material to which they are added (1).

EAFS can be incorporated into bituminous mixtures. In some cases this material has a CE marking as an aggregate for bituminous mixtures in 
accordance with EN 13043/AC (2); this guarantees correct properties required by aggregates for bituminous mixtures. Slag can also be purchased for a similar price to that of other aggregates. In this sense, its use does not compromise the economic viability of the mixture even in large quantities.

Many of these advantages have been reported: Fernández et al. (3) established that the Polished Stone Value (PSV) of EAFS was higher than other conventional aggregates like quartzite gravel and diorite. Similarly, Asi (4) replaced 30\% limestone with EAFS in a bituminous mixture, obtaining a substantial skid resistance improvement as measured with a British Pendulum Tester. Both results were consistent and seem to make the use of EAFS as coarse aggregate for road surfaces particularly recommendable when it comes to improving skid resistance.

Regarding the general features of bituminous mixtures such as stability, water sensitivity, resilient modulus or fatigue life, these features are relatively unaffected and in certain cases improved by the incorporation of EAFS, as reported by Pasetto and Baldo (5).

This article gives close consideration to another attribute of bituminous mixtures that is definitely improved by EAFS; the ability of bituminous mixtures to be heated using microwave energy. It is useful to remember in this respect that several researchers have studied the application of microwave energy to heating bituminous mixtures. Some of the most interesting applications are the possibility of in-place repair of cracked surfaces, removal of damaged mixture during patching, removal of ice from frozen roads and the replacement of fuel or gas as a source of energy in asphalt plants.

Regarding in-place applications, Bosisio et al. (6) reported that the depth of microwave penetration in a bituminous road surface can reach up to $15 \mathrm{~cm}$ for frequencies of $4.5 \mathrm{GHz}$. They also demonstrated that as microwave energy heats the mixture internally, it does not burn the road surface. Al-Ohaly and Terrel (7) were of the same opinion and added that bituminous mixtures heated using microwave energy offered improved water sensitivity, thus were more resistant to moisture damage. These authors maintained that microwave heating can be suitable for in-place repair of cracking or for areas that require the removal of layers due to ruts or potholes. The same conclusion was reached in reference to the manufacture of bituminous mixtures: energy consumption may be reduced and it is possible to retard the aging process of bitumen compared with traditional heating methods.

Benedetto and Calvi (8) recently carried out an interesting study with the aim of verifying the possibility of including microwave heating technology in manufacturing and recycling bituminous mixtures.
The results obtained were very promising. This study included a numerical model that can be applied for designing a prototype of a microwave heating plant.

However, all the researchers above coincided that there is limited capacity for heating bituminous mixtures by microwaves. It depends on the mineralogical characteristics of the aggregates among other factors. For example, basalt or limestone absorb more energy than silica when subjected to radiation with microwave energy (7).

In order to increase the susceptibility of the bituminous mixtures to microwave radiation, certain additives have been used. For example Wang et al. $(9,10)$ used carbonyl iron powder. Gallego et al. (11) added a bituminous steel wool to the mixture. Both cases resulted in a noticeable increase in susceptibility to microwave energy.

This article presents a more recent study on additives for improving the capacity of bituminous mixtures for heating with microwave energy. The experiments were carried out with steel wool, scrap tire wire, silicon carbide, iron filings and EAFS. From the results obtained and their market costs, as well as the simplicity of application at industrial level, the best option appears to be EAFS.

It is interesting to consider that an estimated 8.5 million tons of EAFS are produced every year by the principal European countries (12). Part of this could be used in bituminous mixtures for pavements and road surfaces while helping to solve an environmental issue.

With this intention in mind, some companies committed to waste reuse have already obtained a CE marking of steel slag aggregates (13); a generic trademark given to this type of sub product. This CE marking enables standardized use of slag in bituminous mixtures as any other natural aggregates.

\section{MATERIALS}

In order to reduce variability, the bituminous mixture used for this study was a mortar (sand + bitumen) made with limestone and conventional bitumen. Various additives were used with the objective of improving the susceptibility of the mortar to microwave energy, thereby decreasing the energy consumption necessary to increase its temperature. The following sections describe the characteristics of the bituminous mortar as well as of the additives.

\subsection{Bituminous mortar}

The mortar was made with limestone sand. Calcium carbonate $\left(\mathrm{CaCO}_{3}\right)$ from ground limestone was used as a filler. The resulting grading curve is presented in Table 1 and Figure 1.

A 50/70 penetration bitumen (EN 12591)(14) was used as a binder. The manufacturing temperature of 
the mortar was $160^{\circ} \mathrm{C}$ and the compaction temperature was $148^{\circ} \mathrm{C}$.

In order to determine the optimal binder content for the mixture, Marshall Test specimens were used (EN 12697-30) (15), compacted with 75 blows per side. The binder content was established at $8 \%$ by weight the aggregates, corresponding to approximately $5 \%$ voids in the mixture. The mortar thus had a density of $2.227 \mathrm{~g} / \mathrm{cm}^{3}$ (EN 12697-6) (16) and a Marshall stability of $10.6 \mathrm{kN}$ (EN 12697-34) (17).

Figure 2 shows two halves of a Marshall specimen of bituminous mortar. The limestone sand is the white particles.

\subsection{Additives}

In principle, as indicated above, bituminous mixtures have a low susceptibility to microwave energy. However, greater energy efficiency can be achieved

TABLE 1. Grading curve of the bituminous mortar

\begin{tabular}{lccccc}
\hline Sieve $(\mathrm{mm})$ & 4 & 2 & 0.5 & 0.25 & 0.063 \\
$\%$ Passing & 100.0 & 76.0 & 41.4 & 24.8 & 10.0 \\
\hline
\end{tabular}

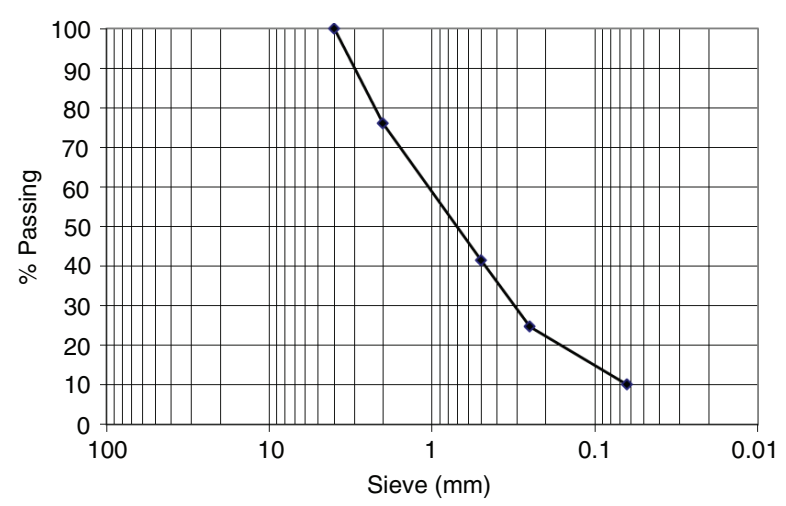

FIGURE 1. Grading curve of the bituminous mortar.

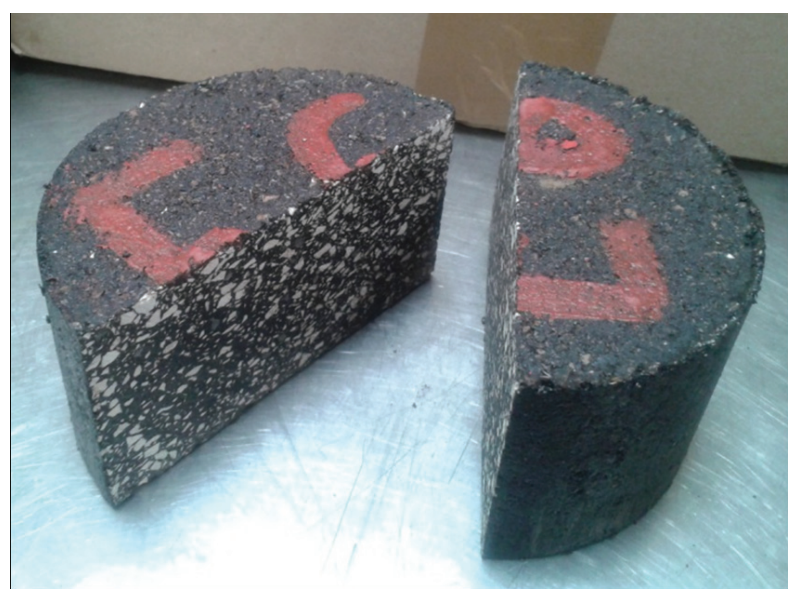

FIgURE 2. Marshall specimen of bituminous mortar split into two halves. during the heating process by incorporating additives that are more susceptible to microwaves.

The first additive used was a metallic fiber. The variable electromagnetic field of the microwaves induces a current that heats the fibers by the Joule effect and the rest of the mixture by direct contact. Granular additives made up of materials containing molecules that are excited by microwaves were also tested. These additives go through an immediate temperature increase and heat the rest of the bituminous mixture by contact. Granular additives have a significant operational advantage over metallic fibers, which tend to form clusters during the preparation of the bituminous mixture. The granular material is distributed homogeneously through the entire mass of the mixture as if it were simply another fraction of the aggregate.

\subsubsection{Metallic fibers and wires}

As for the fibers considered in the study, two kinds of steel wool were used: the first type was a "coarse steel wool", with $0.10-0.12 \mathrm{~mm}$ thick wires, the second type was a "medium steel wool", with a thickness of $0.04-0.06 \mathrm{~mm}$. Steel wool is sold in coils and the fibers were cut into pieces of approximately $10 \mathrm{~mm}$ in length.

As previously observed, both of these fibers have a tendency to form clusters due to the fact that they bend with ease and tangle with one another. Steel wire from shredded end-of-life tires was also used. In this case, the pieces were approximately $10 \mathrm{~mm}$ in length. All of these materials were incorporated in quantities of $0.2 \%$ and $0.4 \%$ by weight of the bituminous mixture.

\subsubsection{Granular additives}

Silicon carbide was one of the granular additives used in the study because of its sensitivity to microwaves. It was also incorporated in proportions of $0.2 \%$ and $0.4 \%$ by weight of the mass of the mixture. Iron filings from an industrial lathe were also used in the same percentages. The fraction size of both additives used was $0.063 / 0.25 \mathrm{~mm}$.

Finally, slag from an electric arc furnace, fraction size $0 / 2 \mathrm{~mm}$, was used to improve the susceptibility of the bituminous mixture due to the high content of metallic compounds. This material was incorporated in quantities of $2 \%, 5 \%, 10 \%$ and $20 \%$ by weight of the mass of the bituminous mixture since this is an alternative aggregate rather than an addition and its price is similar to natural aggregates. Figure 3 shows the appearance of the slag used in the study.

Due to the fact that higher percentages of the slag were added compared to the use of other materials, slag was substituted for aggregates of the same size, 
as mere addition would have caused a significant change to the grading curve of the mortar.

Table 2 shows the original chemical composition of the slag used in the present investigation. This composition shows that after leaving the oven, the contents of $\mathrm{CaO}$ and $\mathrm{MgO}$ were very high and may lead to problems of expansion. For this reason, the company that markets slag as a steel aggregate subjects the aggregate to several months storage in humid conditions in order for it to acquire the necessary hydration and thus minimize expansion before it is used in bituminous mixtures. Likewise, it can be observed that $40 \%$ of the slag was iron oxide, which explains the response to microwaves shown in the following sections. This iron oxide content is very high compared to Blast Furnace Slag (BFS) which is usually below $2 \%$. Due to this higher percentage of iron and subsequent susceptibility to microwave heating, EAFS was chosen rather than BFS.

\section{LABORATORY PROCEDURE}

First of all, the bituminous mortar test specimens were prepared by including the corresponding additives. These test specimens were then subjected to heating in a microwave oven.

The microwave oven used to heat the bituminous mixture in this study had an output of $1200 \mathrm{~W}$ and a $230 \mathrm{~V}, 50 \mathrm{~Hz}$ power supply. The oven produced

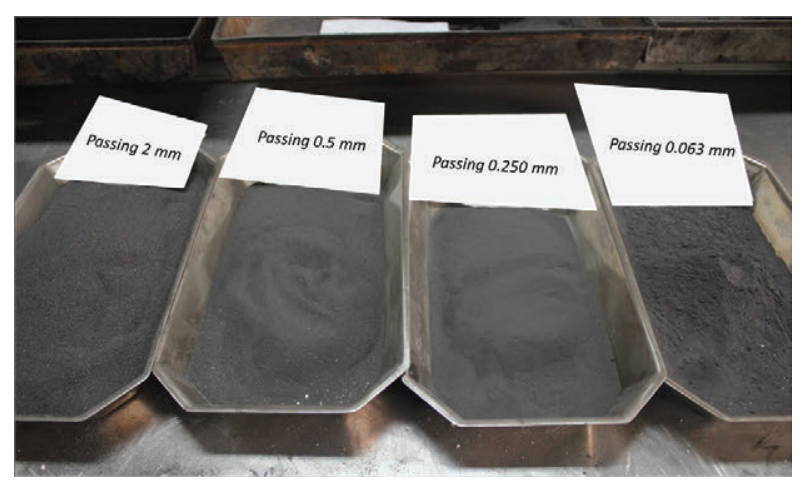

FIGURE 3. EASF fractions after sieving.

TABLE 2. Original chemical composition of slag (before hydration)

\begin{tabular}{lc}
\hline Chemical Composition & $($ \%) \\
\hline $\mathrm{Al}_{2} \mathrm{O}_{3}$ & 8.81 \\
$\mathrm{CaO}$ & 24.28 \\
$\mathrm{Fe}_{2} \mathrm{O}_{3}$ & 40.49 \\
$\mathrm{MgO}$ & 3.02 \\
$\mathrm{MnO}$ & 4.72 \\
$\mathrm{SiO}_{2}$ & 12.60 \\
$\mathrm{P}_{2} \mathrm{O}_{5}$ & 0.36 \\
Other substances & 5.72 \\
\hline
\end{tabular}

microwave heat of up to $800 \mathrm{~W}$, with a frequency of $2.45 \mathrm{GHz}$.

Each bituminous mortar specimen weighed approximately $1000 \mathrm{~g}$. These specimens were placed separately in the microwave oven and heated for periods of $60 \mathrm{~s}$. Between each two consecutive periods, the oven was opened and the surface temperature was measured using an infrared gun. The same procedure was carried out with the specimens containing additives and to the specimens without additives used as a reference.

An electricity meter was used to measure the energy consumption of the oven during the heating of the specimens. It was determined that the power consumed by the microwave oven was not dependent on the additive used. However, the temperature of the specimen was shown to be dependent on the type and proportion of the additive in the mixture.

\section{RESULTS AND DISCUSSION}

The results for the control mixture and the mixture with additives are shown in the following charts (Figures $4-8$ ). On the horizontal axis, each chart shows the energy consumed during the process. These values were obtained minute by minute using an electric meter. The vertical axes on the charts show the superficial temperature of the specimen after each period of heating in the microwave oven.

The figures show that the temperature change of the test specimen was roughly linear. Therefore, the energy temperature points approached a straight regression line, which show correlation coefficients of almost 1 in each case.

In the light of these charts, the different additives and their proportions affected the gradients of the regression lines of the temperature reached against the energy consumed. In order to visualize the results as a whole, figure 9 illustrates these gradients. The greater the slope of the curve, the more susceptible the mixture is to microwave energy.

It may be observed that the most susceptible mixtures to microwave energy were those with EAFS (5-20\% by weight of mass of the mixture), followed by the metal additives: steel wool $(0.2-0.4 \%)$ and scrap tire wire $(0.2-1.6 \%)$. Nevertheless, neither the silicon carbide $(0.2-0.4 \%)$ nor the iron filings $(0.2-0.4 \%)$ had any effect on the heating of the mixture when using microwave energy and with the percentages of the additives used.

When considering the inclusion of these additives in bituminous mixtures on a real scale and for large projects, two fundamental aspects should be taken into consideration: the cost and the viability of including the additives in a homogenous manner into the bituminous mixture manufactured on an industrial scale. 
Use of additives to improve the capacity of bituminous mixtures to be heated by means of microwaves 5
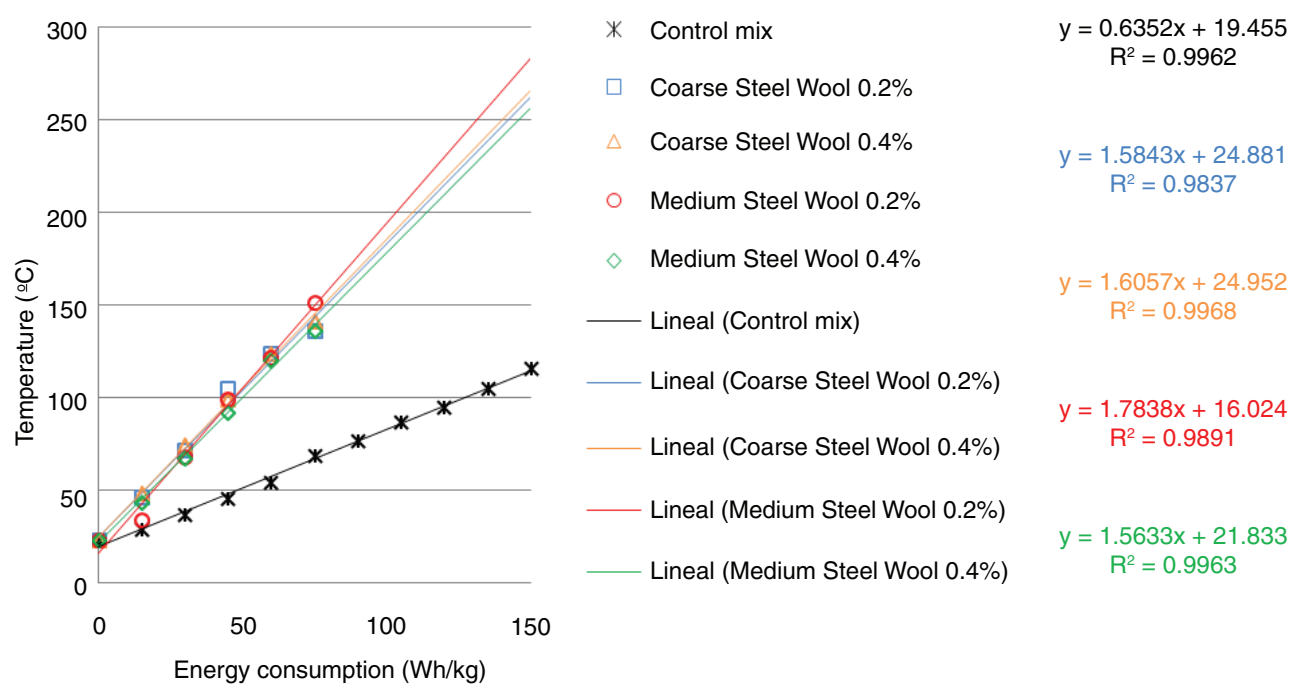

FiguRE 4. Energy consumed - temperature (steel wool).
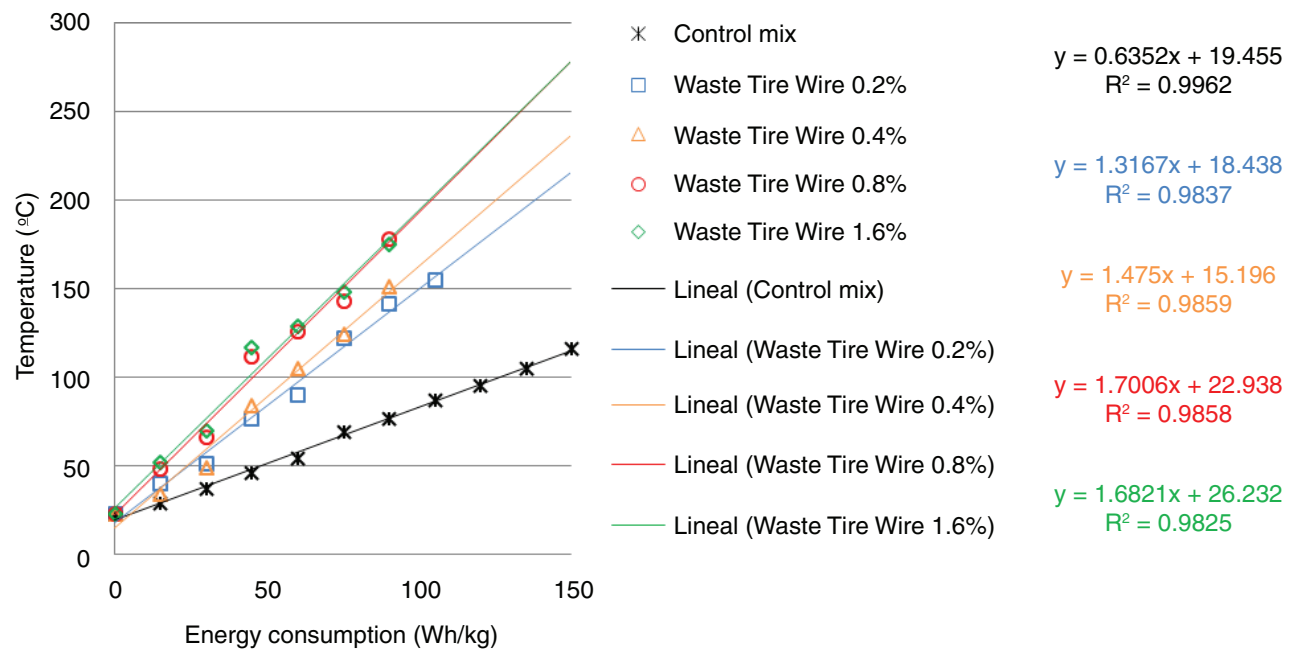

FIGURE 5. Energy consumed - temperature (scrap tire wire).

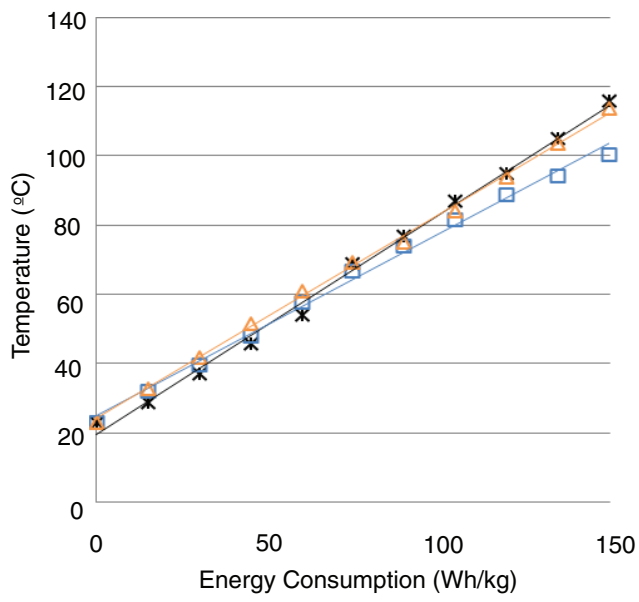

* Control mix

$\square$ Silicon Carbide $0.2 \%$

$\triangle$ Silicon Carbide $0.4 \%$

- Lineal (Control mix)

_Lineal (Silicon Carbide 0.2\%)

$y=0.5892 x+24.034$
$R^{2}=0.9982$

FIGURE 6. Energy consumed - temperature (silicon carbide). 


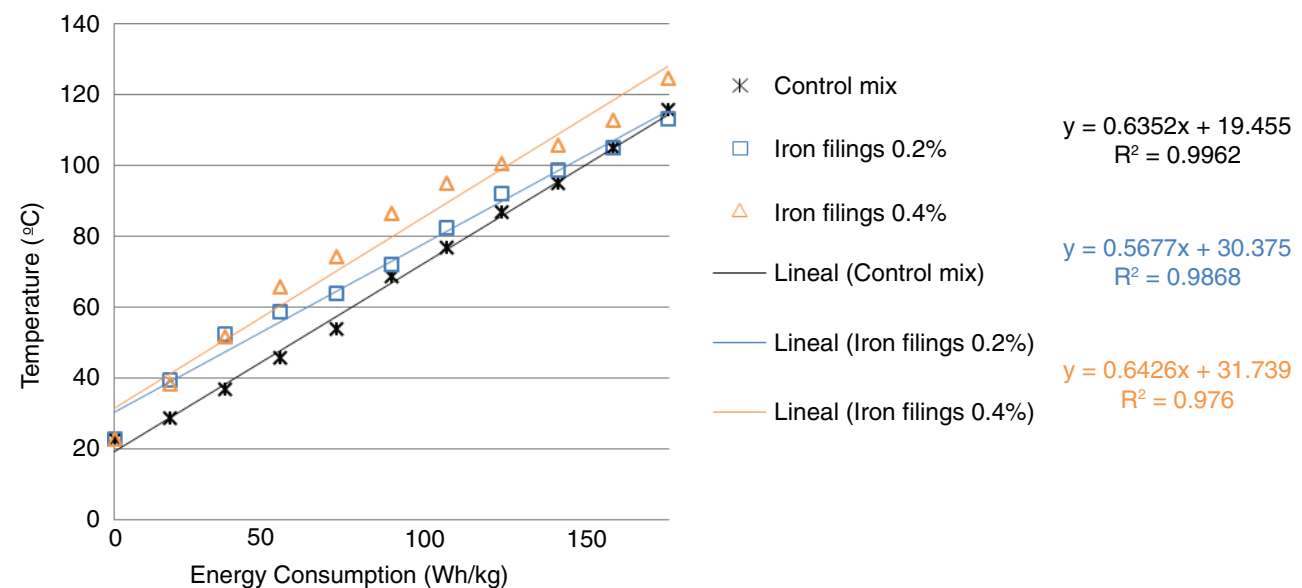

FIgURE 7. Energy consumed - temperature (iron filings).
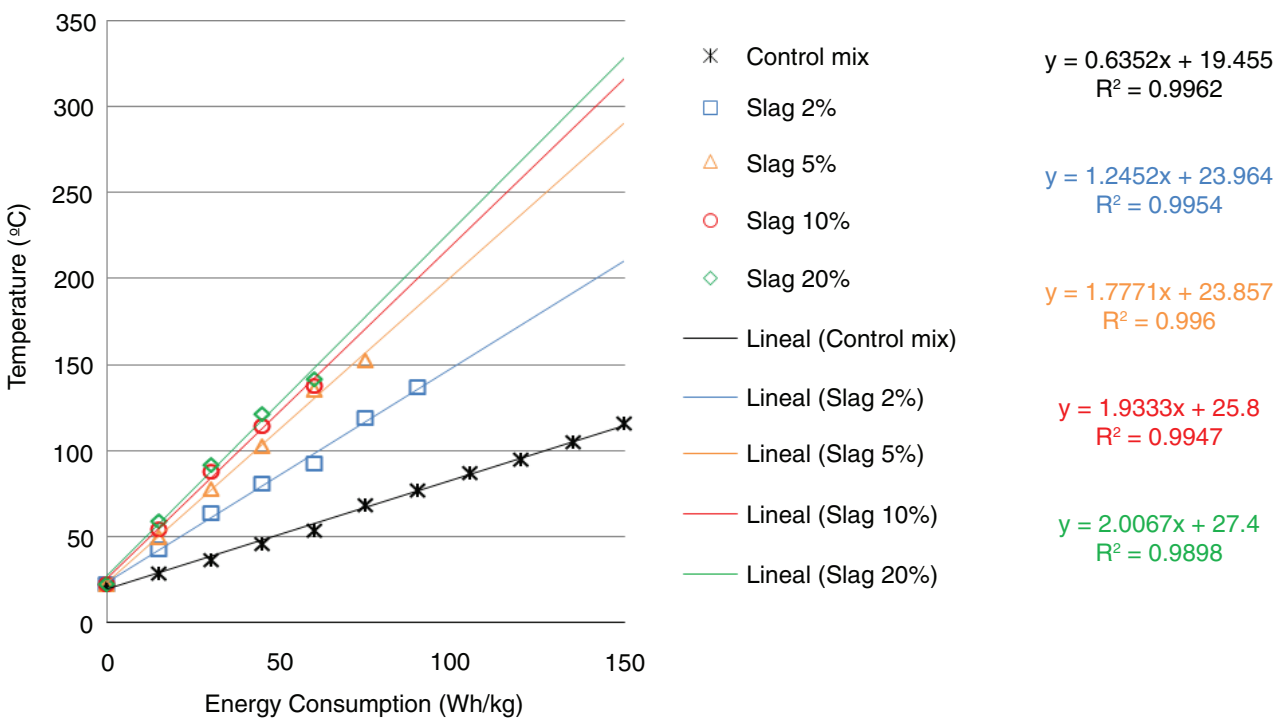

FIGURE 8. Energy consumed - temperature (slag).

From an economic point of view, the inclusion of EAFS by replacing part of the aggregates does not imply an additional cost because at present the cost per ton of EAFS is similar to the prices of natural aggregates (Table 3). However, the addition of steel wool or silicon carbide is very expensive. In the case of scrap tire wire or iron filings, the cost is less due to the fact that it is steel intended for recycling as scrap metal. Although given that this kind of material is not often found on the market, it has not been possible to establish the price at a commercial level.

From a construction point of view, the steel wool tends to get tangled up during the mixing process forming clusters inside the mixture and so uniformity during industrial manufacturing is uncertain. However, EAFS being a granular product similar to other aggregates can be mixed perfectly in an asphalt plant and requires no installation modifications.
Treatment is exactly the same as for natural aggregates normally used in these plants.

\section{CONCLUSIONS}

In light of the results obtained, several conclusions can be drawn. Firstly, bituminous mixtures can be successfully heated using microwave energy. However, their susceptibility to microwave energy is limited and therefore require certain additives in order to make the heating process more energy efficient.

This study considered various additives that increase susceptibility to microwave heating: steel wool, metallic wires, iron filings, silicon carbide and electric arc furnace slag. To compare the effect of these additives, experimental bituminous mixtures were heated using microwaves in 


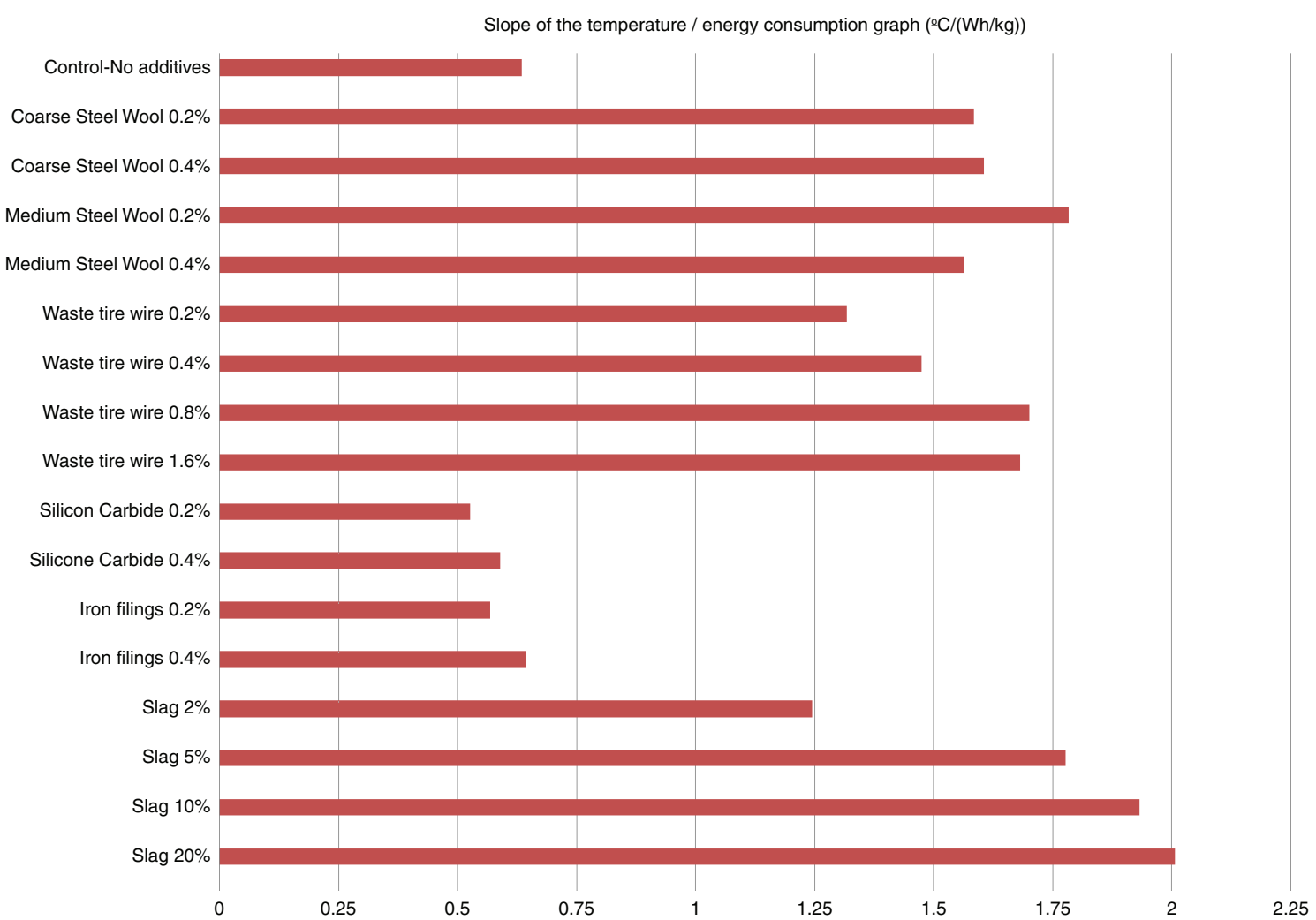

FIGURE 9. Slope of the temperature / energy consumption graphs.

TABLE 3. Market prices of the products used and effect on the price of the bituminous mixture (compiled by authors)

\begin{tabular}{lccc}
\hline MATERIAL & $\begin{array}{c}\text { PRICE } \\
(\boldsymbol{\epsilon} / \mathbf{t})\end{array}$ & $\begin{array}{c}\text { Additive (\%) } \\
\text { over mass of bituminous mixture }\end{array}$ & $\begin{array}{c}\text { PRICE } \\
\text { (€/t bituminous mixture) }\end{array}$ \\
\hline Conventional aggregate & 4.60 & 0 & 42.185 \\
Slag (steel works aggregate) & 4.50 & 2 & 42.182 \\
& & 5 & 42.178 \\
& & 10 & 42.171 \\
Silicon carbide & 1350.00 & 20 & 42.157 \\
& & 0.2 & 45.952 \\
Steel Wool & 3060.00 & 0.4 & 49.719 \\
& & 0.2 & 50.740 \\
Iron filings & $\mathrm{n} / \mathrm{a}^{*}$ & 0.4 & 59.295 \\
Scrap tire wire & $\mathrm{n} / \mathrm{a}^{*}$ & - & - \\
\hline
\end{tabular}

* Not commonly found on the market.

the laboratory. A microwave oven was used with an output of $1200 \mathrm{~W}$ and a $230 \mathrm{~V}, 50 \mathrm{~Hz}$ power supply. The oven can produce microwaves of up to $800 \mathrm{~W}$, with a frequency of $2.45 \mathrm{GHz}$. A mass of material $(1000 \mathrm{~g})$ was heated in the microwave oven resulting in an increase in temperature and energy consumed during the process was measured.
Under the laboratory conditions of this study, the bituminous mixtures heated up much faster by incorporating electric arc furnace slag (5-20\% over the weight of the mixture), steel wool $(0.2-0.4 \%)$ or scrap tire wires $(0.2-1.6 \%)$.

Scrap tire wires are not often found on the market and steel wool has a tendency to form clusters during mixing, which causes a heterogeneous mixture. 
In contrast, due to its granular shape, slag is distributed homogeneously throughout the bituminous mortar, making it possible for conventional asphalt plants to make use of it on an industrial scale without difficulty. Several companies that process slag have already obtained a CE marking for the slag as an aggregate for bituminous mixtures. Furthermore, the price of the slag is similar to that of other aggregates, meaning that the economic viability of the mixture is not compromised.

Furthermore, if we consider the economic and environmental criteria, electric arc furnace slag can be considered an optimal component for the production of bituminous mixtures susceptible to microwave heating, used on a percentage base of at least $5 \%$ by weight of the mixture.

\section{ACKNOWLEDGEMENTS}

This research was developed within the TRAINER Project - "Development of new technology for autonomous, intelligent self-healing of materials" - financed by the Centre for the Development of Industrial Technology (CDTI) of the Spanish Government within the program supporting the National Strategic Consortia for Technical Investigation (CENIT).

The authors wish to acknowledge Raquel Casado, Ana F. Pereira and Carlos Martín-Portugués from Acciona for their contribution to this study.

\section{REFERENCES}

1. Vázquez, E.; Barra, M. (2001) Reactivity and expansion of electric arc furnace slag in their application in construction. Mater. Construcc. 51 [263-264], 137-148. http:// dx.doi.org/10.3989/mc.2001.v51.i263-264.359

2. CEN. EN 13043/AC:2004. Aggregates for bituminous mixtures and surface treatments for roads, airfields and other trafficked areas.
3. Fernández, A.; Alonso, M.A.; López-Moro, F.J.; Moro, M.C. (2013) Polished Stone Value Test and its relationship with petrographic parameters (hardness contrast and modal composition) and surface micro-roughness in natural and artificial aggregates. Mater. Construct. 63 [311], 377-391. http://dx.doi.org/10.3989/mc.2013.mc.00912

4. Asi, I.M. (2007) Evaluating skid resistance of different asphalt concrete mixes. Build. Environ. 42 [1], 325-329. http://dx.doi.org/10.1016/j.buildenv.2005.08.020

5. Pasetto, M.; Baldo, N. (2011) Mix design and performance analysis of asphalt concretes with electric arc furnace slag. Constr. Build. Mater. 25 [8], 3458-3468. http://dx.doi. org/10.1016/j.conbuildmat.2011.03.037

6. Bosisio, R.G.; Spooner, J.; Granger, J. (1974) Asphalt road maintenance with a mobile microwave power unit. J.Microwave.Power. EE. 9 [4], 381-386. http://dx.doi.org/10. 1080/00222739.1974.11688936

7. Al-Ohaly, A.A.; Terrel, R.L. (1988) Effect of microwave heating on adhesion and moisture damage of asphalt mixtures. Transport.Res. Rec. 1171, 27-36. Transportation Research Board. National Research Council. Washington, D.C.

8. Benedetto, A.; Calvi, A. (2013) a pilot study on microwave heating for production and recycling of road pavement materials. Constr.Build.Mater. 44, 351-359. http://dx.doi. org/10.1016/j.conbuildmat.2013.02.082

9. Wang, Z.J.; Zhao, P.; Ai, T.; Yang, G.Y.; Wang, Q. (2011) Microwave absorbing characteristics of asphalt mixes with carbonyl iron powder. Prog.Electromagn. Res. 19, 197-208. http://dx.doi.org/10.2528/PIERM11052312

10. Wang, Z.; Wang, S.; Ai, T.; Zhao, P. (2014) Laboratory preparation and microwave heating test of CIPs/Asphalt binder. Pavement Materials, Structures, and Performance GSP 239, 1-8. http://dx.doi.org/10.1061/9780784413418.001

11. Gallego, J.; Del Val, M.A.; Contreras, V.; Páez A. Heating asphalt mixtures with microwaves to promote self-healing. Constr. Build. Mater. 42, 1-4. http://dx.doi.org/10.1016/j. conbuildmat.2012.12.007

12. Statistics 2010. Association of Metallurgical Producers and Processors. Duisburg-Rheinhausen, Germany.

13. ADECGLOBAL Eco-integración Ambiental. Ficha técnica de Producto. Marcado CE: Arido siderúrgico 9/5 $\mathrm{G}_{\mathrm{A}}$ 85. In accordance with EN 13043:2002 + AC:2004.

14. CEN. EN 12591:2009. Bitumen and bituminous binders. Specifications for paving grade bitumens.

15. CEN. EN 12697-30:2006. Test methods for hot mix asphalt. Part 30: Specimen preparation by impact compactor

16. CEN EN 12697-6:2003. Bituminous mixtures. Test methods for hot mix asphalt. Part 6: Determination of bulk density of bituminous specimens.

17. CEN. EN 12697-34:2007. Bituminous mixtures. Test methods for hot mix asphalt. Part 34: Marshall Test. 